\title{
Is science special?
}

\author{
In a time of recession, will a new UK government invest sufficiently in science?
}

"You've never had it so good" is the famous phrase (or rather, paraphrase) of Harold Macmillan, used when he addressed a party meeting as British Prime Minister in 1957. Macmillan's words would also seem to be true of British science or, at least, they were. Since the election of the present Labour government in 1997, science has seen a marked growth in funding (alongside a burgeoning economy, admittedly) that has more than reversed the downward trend for funding that began under Margaret Thatcher's government in the 1980s. Now, as the country faces a long haul out of recession that will undoubtedly entail stringent cuts in public spending, and a general election looms, the future for science in Britain certainly doesn't look good.

Britain is not alone in facing up to the financial crisis. Yet elsewhere in the world steps have already been taken to bolster investment in science, notably in the stimulus packages devised by the governments of the United States, France and Germany. In Japan at the end of last year, the newly elected administration stepped back from the huge cuts that had been threatened for the country's science programme. Last month, Canada announced increased funding for science - a modest increase, that barely offset the cut made in the previous year, but sufficient for Canada to remain the country within the G7 that spends the highest proportion of its GDP on university-based research.

Britain has long been said to 'punch above its weight', in terms of the returns on science investment. The attractive statistics - that, holding $1 \%$ of the world's population, Britain produces $7.9 \%$ of all publications and claims $11.8 \%$ of the citations, rising to $14.4 \%$ of citations with the highest impact ${ }^{1}$ - have made the country a net importer of scientists from abroad, even though the R\&D spend of British businesses is consistently lower as a percentage of GDP than that of its competitors. In the face of increased competition from such nations as China, India and Brazil, and the successful science-based economy of Singapore, can Britain hope to maintain its record?

Setting the issue of recession aside, intimations of a growing crisis in the funding of British science had already emerged in 2009, as the finances of one of its largest funding bodies, the Science and Technology Facilities Council (STFC), began to unravel. The STFC was set-up in 2007 to manage all principal physics programmes and facilities in the UK, and to honour international subscriptions, including that to CERN. Even at the STFC's conception, scientists voiced concern that the lumping together of so many cost streams would lead to trouble and it did. Immediately, the STFC budget proved to be insufficient to cover all of its responsibilities, particularly the exploitation of the newly built Diamond synchrotron facility, at the Rutherford Appleton Laboratory in Oxfordshire. There has been no government bail-out of the STFC. Instead, in recent months British researchers have had to face up to a $25 \%$ cut in studentships and postdoctoral positions and the pull-out from international projects such as the Gemini telescopes.

Last month another axe fell, when the Higher Education Funding Council for England (HEFCE) announced a $£ 449$ m cut for the coming year. Three-quarters of UK institutions will experience the first real-terms decrease since 1997; unions are claiming as many as 9,000 job losses by 2013 . However, what money there is is being increasingly targeted at science, engineering and mathematics.

The recession-induced cutting has begun, but where it stops nobody knows. All three of the UK's main political parties are reticent on the subject of public-spending cuts in the run-up to the next general election - heavily touted to take place on the 6 May, although not yet called (as Nature Physics went to press). The uncertainty of the date is mirrored in the polls, which suggest that the outcome might be a hung parliament, something not experienced in Britain since the 1970s. It will be an unusual result from an unusual process, one that will now include televised debates between the leaders of the three major parties and an increasing media focus on their wives.

Even if one party does receive a strong mandate - or manages to create a strong enough coalition - will science have much profile, against the funding demands of such departments as defence or health? As John Womersley, director of scientific programmes for the STFC, has said" "There's likely to be a tough scramble over how the budget will be allocated. The question is: is science special?"

Fortunately there are many who think it is. A raft of recent reports have all called on the nation's leaders to continue to invest in science, as the surest means of underpinning long-term economic recovery and development - as so many other nations are already doing. The message comes loud and clear from $A$ Vision for UK Research ${ }^{3}$ produced by the Council for Science and Technology, the prime minister's advisory body; from Physics: an investment of the future $^{4}$, a manifesto for the general election prepared by the Institute of Physics; and from The Scientific Century: securing our future prosperity ${ }^{1}$ from the Royal Society (endorsed by former science ministers William Waldegrave and David Sainsbury, who served Conservative and Labour governments, respectively).

All three reports are specific and detailed in their recommendations. Alongside the call for continued financial investment, the need to invest in people is stressed - be it at the level of general science education, the training (and retaining) of science teachers, or the lengthening of UK PhDs to a four-year programme. The Royal Society's report in particular, intending to "provoke a richer debate about the contribution that science and innovation will make to the UK's future", comments on how to strengthen both the UK's position as a global hub for science and the UK government's use of science.

All three documents make a sound case for science being special. Indeed, they are a ready-made science policy. The incoming government, whoever it is, should read them, and take their message on board.

\footnotetext{
References

1. http://royalsociety.org/The-scientific-century/

2. Brumfiel, G. Nature 463, 410-411 (2010).

3. www.cst.gov.uk/reports/files/vision-report.pdf

4. www.iop.org/aboutus/file_39015.pdf
} 